\title{
US administration tries to repair green image
}

\section{Mark Schrope}

Following public criticism of its decisions on arsenic pollution and global warming, President George W. Bush's administration last week sought to bolster its green credentials with a barrage of pro-environment announcements.

On 18 April, the Environmental Protection Agency (EPA) said it was asking the National Academy of Sciences for a lightning study of the health effects of arsenic in drinking water. The agency wants to establish an appropriate standard for arsenic levels, having rejected one put forward by the Clinton administration (see Nature 410, 503; 2001).

The EPA also said it would accept a number of other controversial environmental rules put in place during the last days of the Clinton administration. One would protect wetlands by closing a legal loophole that, under certain conditions, allows land developers to dredge and bulldoze these areas. Another will require more businesses to report how much lead they release into the environment.

The White House issued statements supporting the EPA's action, timed for the run-up to Earth Day, a public celebration of environmental progress in the United States, held on 22 April. But some business groups opposed the moves, and said that they plan to challenge the new rules in the courts.

On 19 April, the president announced that he would sign an international treaty,

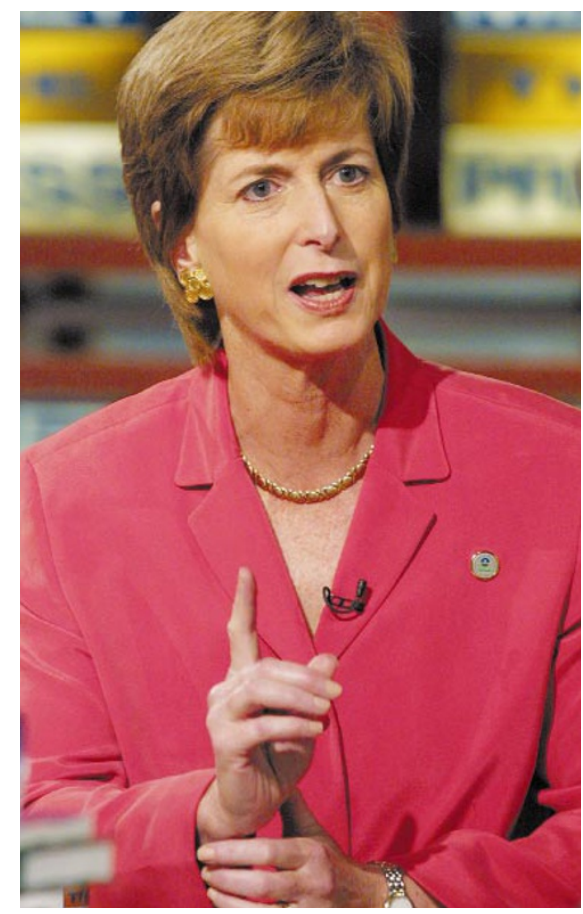

Finger on the pulse: Christie Whitman promises new standards for arsenic in drinking water.

agreed under the Clinton administration, to phase out production and use of persistent organic pollutants such as polychlorinated biphenyls and the pesticide DDT.

But environmentalists are sceptical. "This is basically a public relations ploy," says
Elliott Negin, a spokesman for the Natural Resources Defense Council. He adds that he doubts whether the EPA will enforce the lead and wetlands rules with sufficient vigour.

White House spokesman Ari Fleischer denies that Bush is concerned about his environmental image, saying that the plans "represent a balanced approach to protecting America's environment”.

To develop its arsenic standard, the EPA wants the National Academy to update its 1999 report on the health effects of arsenic in drinking water. Gary Carlson, a toxicologist at Purdue University in West Lafayette, Indiana, who was on the panel that produced the 1999 report, says that there is some value in updating it.

Carlson says the main issue is whether or not there is a threshold below which arsenic's effects are negligible. But scientists disagree on this fundamental point, which is why the 1999 study did not recommend a 'safe' level of arsenic, and why some argue that the decision to set a regulatory level is essentially political, rather than scientific.

EPA administrator Christie Whitman says that a new standard will be formulated by February 2002 and that compliance with it will be required by 2006, just as it would have been with the rule proposed by the Clinton administration. The EPA will also ask the National Drinking Water Advisory Council to examine economic issues related to arsenic reductions.

\section{Tenure-track plan aims to end university inbreeding}

\section{Xavier Bosch, Barcelona}

Spain has introduced a new career track for young researchers. The initiative aims to increase competition and eliminate the academic patronage that critics say hampers the development of Spanish science.

The Ramón y Cajal programme, named after the Nobel-prizewinning neuroscientist,

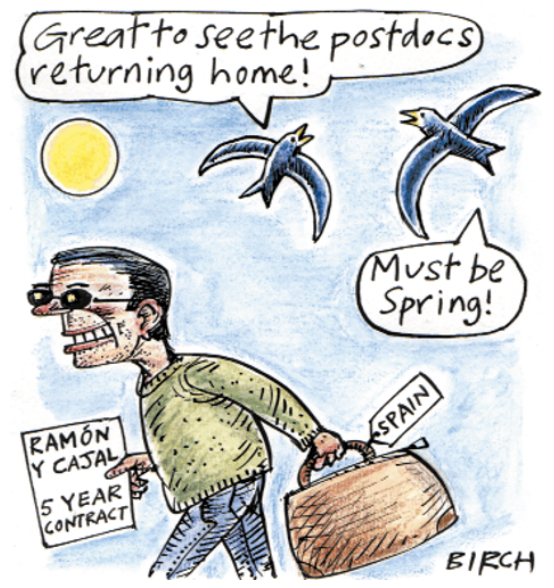

will offer five-year contracts to 2,000 postdoctoral fellows over the next two years. Conditions under the new programme - which will name its first 800 fellows this year - will be far better than under the existing Spanish postdoc recruitment system. In addition to a higher salary Ptas 4.75 million (US\$26,000), compared with Ptas 2.9 million - and a contract of five years instead of three, Cajal postdocs will be allowed to lead research projects of their own.

University departments and research centres wishing to join the programme must submit a seven-year plan, covering research and personnel, to prove they will be able to offer permanent positions afterwards. External panels of scientists will evaluate all postdocs' progress after two and four years.

In a clear effort to increase movement between centres, applicants must have spent 18 months working somewhere other than their place of application. The programme will lead to "an improved quality of research, easier mobility and less 'inbreeding", said the Ministry of Science and Technology, announcing the programme last week.

The initiative marks “an important change in mentality”, says Ramon Marimon, the science ministry's secretary of state. "It's a turning point for research careers in Spain as it introduces the concept of tenure track and, by opening up research centres' planning procedures to public view, it should guarantee the sustainable growth of research positions."

Eugenio Santos, director of the University of Salamanca's Cancer Research Institute, says that "for the first time" Spain will have a tenure-track system that is up to international standards of competition and evaluation. He says the programme should attract "a large pool of well-trained young Spanish scientists" who have completed postdoctoral periods abroad and now want to develop their research careers.

Jordi Petriz, a postdoc working on stemcell research at the University of Barcelona, says he welcomes the "leadership and continuity" the system will offer. 